\title{
'n Moontlike model vir die bewerking van idiome in tweetalige woordeboeke*
}

\author{
Liezl Potgieter, Departement Afrikaans en Nederlands, Universiteit van \\ Stellenbosch, Stellenbosch, Republiek van Suid-Afrika \\ (liezlpotgieter@gmail.com)
}

Opsomming: Woordeboeke is belangrike en noodsaaklike hulpmiddels vir vertalers, maar tog het baie vertalers gemengde gevoelens veral oor tweetalige woordeboeke. Terwyl hulle aan die een kant nie werklik daarsonder kan werk nie, bied tweetalige woordeboeke aan die ander kant dikwels vir vertalers min of geen leiding nie. Dit blyk ook dat tweetalige woordeboeke 'n onvoldoende hulpmiddel vir professionele vertalers by die vertaling van idiome is. Die vertaling van idiome behels meer as net die vertaling van enkelwoorde. In hierdie artikel word 'n moontlike model aangebied om die bewerking van idiome in tweetalige woordeboeke te help verbeter.

Sleutelwoorde: IDIOOM, TWEETALIGE WOORDEBOEK, VERTAALEKWIVALWENT, ABSOLUTE EKWIVALENSIE, GEDEELTELIKE EKWIVALENSIE, DIVERGENSIE, ZERO-EKWIVALENSIE, SURROGAATEKWIVALENSIE, REGISTERVERSKILLE, ONVASTHEDE, TAALBOUSELS

\begin{abstract}
A possible model for the treatment of idioms in bilingual dictionaries. Dictionaries are important and necessary resources for translators, but translators nevertheless have mixed feelings particularly about bilingual dictionaries. While on the one hand they cannot really work without them, bilingual dictionaries on the other hand often give translators little or no help. It also appears that bilingual dictionaries are an insufficient resource for professional translators when translating idioms. The translation of idioms entails more than just the translation of single words. In this article, a possible model is presented to help improve the treatment of idioms in bilingual dictionaries.
\end{abstract}

Keywords: IDIOM, BILINGUAL DICTIONARY, TRANSLATION EQUIVALENT, ABSOLUTE EQUIVALENCE, PARTIAL EQUIVALENCE, DIVERGENCE, ZERO-EQUIVALENCE, SURROGATE EQUIVALENCE, DIFFERENCES IN REGISTER, VARIABLE UNITS, LANGUAGE UNITS

* Hierdie artikel is 'n uittreksel uit 'n ongepubliseerde M.A.-skripsie deur Liezl Gouws, Die bewerking van idiome in tweetalige woordeboeke: 'n probleem vir vertalers?, wat in April 2006 aan die Universiteit van Stellenbosch, Stellenbosch, Republiek van Suid-Afrika, voltooi is.

Lexikos 18 (AFRILEX-reeks 18: 2008): 190-206 


\section{Inleidend}

In every language, human beings use idioms. In every language, those idioms share a common property. Decompose any idiom into its constituent words, look at the meaning of those words, and there is no way to reconstruct the idiom. In other words, the word-for-word interpretation of any idiom makes no sense whatsoever. Unless you have a dictionary specifically for translating Englishlanguage idioms, give up any hope of translating them. (Weiss 2004)

Die vertaling van idiome veroorsaak talle probleme vir vertalers. Die huidige bewerking van idiome in tweetalige woordeboeke dra geensins daartoe by om vertalers te help om die taak van vertaling te vergemaklik nie.

Alhoewel die ideale oplossing vir die vertaler se probleem 'n volledige lys ten volle bewerkte idiome as buiteteks, of andersins die insluiting van idiome as volwaardige hooflemmas in die vertikale ordening van die sentrale lys sal wees, is daar om praktiese redes, maar ook vanuit die leksikografieteorie talle beperkings en randvoorwaardes wat in gedagte gehou moet word.

' $n$ Lys idiome as ' $n$ buiteteks is 'n gerieflike manier om idiome aan te bied en te bewerk, maar dis dikwels problematies. Die alfabetiese lysting van idiome kan 'n baie ingewikkelde saak wees, omdat dit moeilik is om te bepaal hoe die idioom gelys moet word en die woordorde van die idioom dikwels ook afhang van die teks en konteks waarbinne dit gebruik word. Dit alles maak dit vir die leksikograaf moeilik om idiome op 'n suksesvolle en gebruikersvriendelike wyse binne 'n buiteteks aan te bied en te bewerk. Gevolglik moet daar na alternatiewe aanbiedings- en bewerkingsmoontlikhede gesoek word.

In hierdie artikel word daar na 'n moontlike model vir die verbeterde bewerking van idiome in tweetalige woordeboeke gekyk om te verseker dat dit gebruikersvriendeliker vir vertalers is.

\section{Aanbieding}

Die onvoldoende manier van aanbieding van idiome in tweetalige woordeboeke is een van die redes waarom hierdie woordeboeke vertalers nie genoegsaam help tydens die vertaling van idiome nie.

Tans word idiome en hulle vertaalekwivalente in tweetalige woordeboeke aangebied as deel van die semantiese kommentaar van die lemmas waaronder hulle aangetref word. Gevolglik word hulle gewoonlik tussen die voorbeeldmateriaal gevind. Alhoewel die idioom op sigself 'n leksikale item is wat eintlik lemmastatus behoort te hê, maak dit in huidige woordeboeke slegs deel uit van die mikrostruktuur. Hierdie werkswyse ontken nie net die status van idiome as leksikale items nie, maar impliseer dikwels ook 'n semantiese verband tussen ' $n$ idioom en die voorafgaande hooflemma. Tog is daar talle ander maniere waarop idiome binne die sentrale teks aangebied kan word wat nie net die bewerking gebruikersvriendeliker sal maak nie, maar ook vertalers sal help om 
vinnig en maklik by die korrekte idioom en 'n gepaste vertaalekwivalent uit te kom.

Een van die eerste veranderinge wat leksikograwe kan aanbring om die bewerking van idiome te verbeter, is om idiome te verhef tot makrostrukturele bewerkingseenhede.

'n Onderskeid kan getref word tussen 'n makrostruktuur met 'n vertikale ordening van lemmas en een met ' $n$ vertikale en 'n horisontale ordening (Gouws en Prinsloo 2005: 95). Tradisioneel word slegs vertikaal geordende lemmas as hooflemmas gesien, terwyl horisontaal geordende lemmas gewoonlik lemmas met slegs sublemmastatus is.

Een van die hoofredes waarom leksikograwe horisontale ordening gebruik, is om plek te probeer bespaar. Daar kan ook verdere teksverdigting en plekbesparing bewerkstellig word deur die lemmas se gemeenskaplike aanvangselement weg te laat en met 'n plekbesparingsmerker soos byvoorbeeld ' $n$ tilde ( ) te vervang. In artikel 1 uit Groot Woordeboek (voortaan GW) kan gesien word hoe die horisontale ordening van lemmas by "bacon" en "bacterial" verder verdig word met behulp van die tilde. In gevalle waar leksikograwe by die horisontale ordening teksverdigting gebruik, kan die gebruiker slegs die lemma via die vertikaal geordende hooflemma bereik. Dit is dus 'n omslagtige proses om by die korrekte vertaalekwivalent van 'n lemma soos byvoorbeeld "bacon rind" uit te kom (sien Artikel 1).

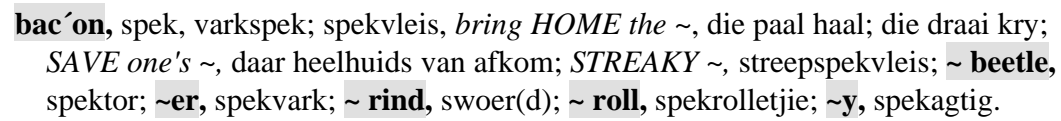

Artikel 1: "bacon", "Baconian" en "bacterial" (uit GW)

Sulke lemmas wat deur 'n plekbesparingsmerker en 'n lemmadeel verteenwoordig word en wat slegs via die voorafgaande voluitgeskrewe hooflemma en/of via 'n lemmadeel in 'n nis- of neseksterne ingangsposisie bereik kan word, staan as sublemmas bekend.

asyn'. Suur vloeistof deur gisting verkry, bestaande uit water en asynsuur; asynagtig; asynbottel; asynekstrak; asynerig; asynflessie; asynlug; asynmakery; asynmoer; asynsmaak; asynsout; asynstandertjie; asynsuur; asynvaatjie.

Artikel 2: "asyn" (uit VAW)

In gevalle waar die horisontaal geordende lemmas nie verdig is nie, maar volledig uitgeskryf word soos in Artikel 2 uit Verklarende Afrikaanse Woordeboek 
(voortaan VAW), is die voorafgaande vertikaal geordende lemma nie die enigste manier om die horisontaal geordende lemmas te bereik nie, sodat dit vir die woordeboekgebruiker heelwat makliker is om by die betrokke horisontaal geordende lemma uit te kom. In gevalle waar die horisontaal geordende lemmas volledig uitgeskryf word en ' $n$ streng alfabetiese ordening handhaaf, funksioneer hulle dus nie as sublemmas nie, maar as volwaardige hooflemmas.

Die lys idiome as vertikale hooflemmas is problematies, omdat dit moeilik is om te bepaal waar in die sentrale alfabetiese lys die idiome gelys moet word. Tog is dit belangrik dat die idiome nie slegs deel sal uitmaak van die woordeboek se mikrostruktuur en saam met die voorbeeldmateriaal aangebied word nie, maar dat hulle vollediger bewerk sal word. Deur idiome in die woordeboek as horisontaal geordende lemmas in te sluit, word die probleem uitgeskakel wat sal ontstaan as die idiome vertikaal georden sou word, terwyl dit steeds vir die woordeboekgebruiker maklik is om die idioom op te spoor waarvoor 'n vertaalekwivalent gesoek word. Sodoende kan die idioom van 'n bewerking voorsien word en is die vertikaal geordende lemma nie die enigste manier om by die idioom uit te kom nie. Die aanbieding van idiome in GW en Pharos 1 Afrikaans-Engels Woordeboek (voortaan PAEW) sal dus soos in Artikel 3 en Artikel 4 daar uitsien.

bac' on, spek, varkspek; spekvleis, bring HOME the bacon, die paal haal; die draai kry; SAVE one's bacon, daar heelhuids van afkom; STREAKY , streepspekvleis; beetle, spektor; er, spekvark; rind, swoer(d); roll, spekrolletjie; y, spekagtig.

Artikel 3: "bacon" (aangepas uit GW) ${ }^{\dagger}$

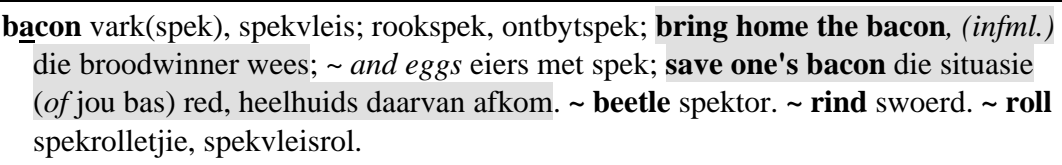

Artikel 4: "bacon" (aangepas uit PAEW)

Leksikograwe kan verder gaan en die aanbieding van idiome in tweetalige woordeboeke verder verbeter deur 'n nuwe tipe neslemmatisering te gebruik. Neslemmatisering kom voor wanneer die leksikograaf van ' $n$ streng alfabetiese ordening afwyk en al die lemmas binne een nes plaas, eerder as om nislemmatisering te gebruik en die lemmas volgens 'n streng alfabetiese ordening te rangskik.

In die geval van nislemmatisering word sowel die vertikale as horisontale lemmas en sowel die hoof- as sublemmas streng alfabeties georden en word daar nie afgewyk van dié ordening nie. Die lemmas binne die nis toon ook 'n interne alfabetiese ordening wat die volgende vertikaal geordende lemma voorafgaan. Nislemmatisering sien soos in Artikel 5 daaruit. 


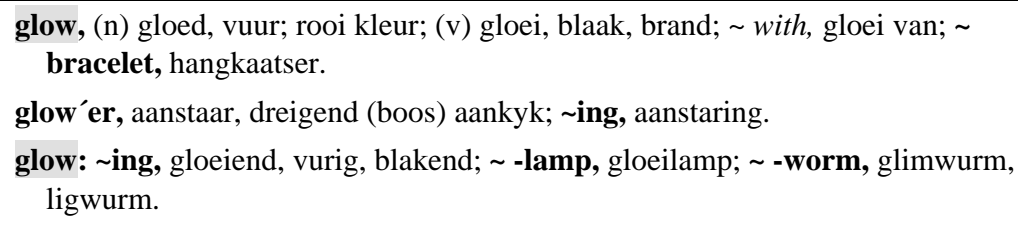

Artikel 5: "glow" (uit GW)

In die geval van neslemmatisering sien dieselfde lemma soos in Artikel 6 daaruit:

glow $n$. gloed; vuur; rooi kleur; skynsel; blosende kleur; be in $a \sim$, (fig.) gloei, gloeiend wees. glow ww. gloei; brand; smeul; skyn; straal; $\rightarrow$ GLOWING adj.; with ... brand/gloei van ...; keep on $\sim$ ing nagloei. $\sim$ lamp gloeilamp. $\sim$-worm glimwurm(pie), ligkewer; $\rightarrow$ FIREFLY.

glower ...

Artikel 6: "glow" (uit PAEW)

By die lemmas waar daar neslemmatisering gebruik word, kom daar dus as 't ware teksblokke met die verskillende tipes inligting in tot stand, maar vorm dit steeds ' $n$ geheel, of ' $n$ nes. Indien leksikograwe die aanbieding van idiome in tweetalige woordeboeke verder wil verbeter nadat daar aan die idiome sublemmastatus gegee is, kan neslemmatisering gebruik word om teksblokke binne die artikeltrajek te vorm. Teksblokke bring mee dat soortgelyke datatipes saamgegroepeer word. Hierdie soeksones kan byvoorbeeld binne die artikel die volgende behels: benewens blokke vir elk van die vertaalekwivalente tesame met hul semantiese subkommentare met genoegsame konteksleiding en/of voorbeeldmateriaal, ook ' $n$ blok vir kollokasies. Binne die artikeltrajek kan dit 'n blok vir sublemmas insluit. Afsonderlike teksblokke vir idiome kan dan ook aan die artikel van die hooflemma geheg word. Deur hierdie teksblokke vir die bewerking van idiome aan te wend, word verseker dat die idiome nie tussen die ander voorbeeldmateriaal aangebied word nie, maar maklik is om raak te sien en te gebruik omdat die idiome nou 'n prominente posisie as makrostruktuuritems kry. Met behulp van 'n kitstoegangstruktuur kan die teksblok met idiome ook verder vir die gebruiker deur middel van struktuurmerkers soos byvoorbeeld IDM. of UITDR. uitgelig word. Indien teksblokke soos in Artikel 7 en Artikel 8 gebruik sou word, sal dit soos volg daar uitsien:

bac' on, spek, varkspek; spekvleis, streepspekvleis; STREAKY ; beetle, spektor; er, spekvark; rind, swoer(d); roll, spekrolletjie; y, spekagtig.

IDM.: bring HOME the , die paal haal; die draai kry; SAVE one's , daar heelhuids van afkom.

Artikel 7: "bacon" (aangepas uit GW) 
baccon vark(spek), spekvleis; rookspek, ontbytspek; and eggs eiers met spek;

beetle spektor. $\sim$ rind swoerd. roll spekrolletjie, spekvleisrol.

IDM.: bring home the bacon, (infml.) die broodwinner wees; save one's bacon die situasie (of jou bas) red, heelhuids daarvan afkom.

Artikel 8: "bacon" (aangepas uit PAEW)

Indien al die voorgestelde verbeterings ten opsigte van die aanbieding van idiome nou saamgevoeg sou word, sal die nuwe verbeterde artikel vir die lemma "bacon" soos volg lyk:

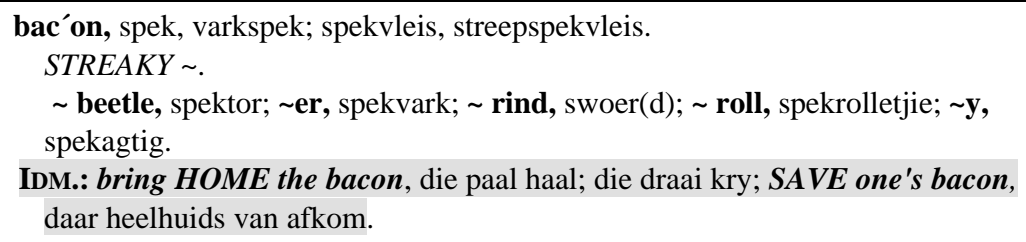

Artikel 9: "bacon" (aangepas uit GW)

Deur afsonderlike teksblokke vir die koteksinskrywings en die sublemmas te skep, kan die mikrostruktuur van die artikel en daarmee saam ook die aanbieding van idiome genoegsaam verbeter word sodat die woordeboekgebruiker maklik kan sien in watter geval die teks 'n sublemma, 'n kollokasie, 'n voorbeeldsin of ' $n$ idioom is. Omdat die idiome ook as horisontaal geordende sublemmas binne 'n aparte teksblok aangebied word, help dit vertalers om vinnig en maklik die idioom op te spoor waarna hulle soek. Vertalers se soektog na 'n idioom in die doeltaal waarmee 'n brontaalidioom vertaal kan word, sal op dié manier aansienlik vergemaklik word.

\section{Vertaalekwivalente}

Die aanbieding van idiome in tweetalige woordeboeke is nie die enigste probleem nie. Die vertaalekwivalente wat verskaf word, sowel as die bewerking daarvan is dikwels ' $n$ selfs groter probleem vir vertalers wanneer dit kom by die korrekte vertaling van idiome.

In die volgende gedeelte sal gekyk word na verskeie moontlike oplossings wat betref die probleem van idiome, hul vertaalekwivalente en hul bewerking in tweetalige woordeboeke.

\subsection{Ekwivalensie}

Gebruikers raadpleeg meestal tweetalige woordeboeke op soek na 'n vertaalekwivalent waarmee ' $n$ spesifieke woord, uitdrukking of idioom in die brontaal in die doeltaal vervang kan word. Vertalers raadpleeg dus woordeboeke om 
hulle te help nie net met teksresepsie nie, maar ook met teksbegrip en teksproduksie. Tog is gevind dat daar aan gebruikers weinig konteks- en koteksleiding verskaf word sodat hulle kan weet watter vertaalekwivalent om binne watter konteks of situasie te gebruik. Hierdie tekort aan konteks- en koteksleiding maak dit vir gebruikers baie moeilik om kommunikatiewe ekwivalensie te bereik.

Wanneer vertalers tweetalige woordeboeke tydens die vertaling van idiome gebruik, is dit omdat hulle op soek is na 'n korrekte vertaalekwivalent vir ' $n$ betrokke idioom. Dit is daarom belangrik dat leksikograwe sal aandag gee nie net aan die verskaffing van vertaalekwivalente nie, maar ook aan die voorsiening van genoegsame konteks- en koteksleiding om die vertaler te help om vinnig en maklik die korrekte vertaalekwivalent op te spoor en reg te gebruik. Erkenning van idiome as sublemmas behoort ook tot ' $n$ volwaardige bewerking te lei. Hierdie konteks- en koteksleiding kan aangebied word in die vorm van voorbeeldmateriaal en addisionele inligting (byvoorbeeld glosse).

In gevalle waar daar ' $n$ verhouding van absolute ekwivalensie tussen die brontaalidioom en die doeltaalidioom bestaan, is daar dus sowel semantiese as kommunikatiewe ekwivalensie tussen die bron- en doeltaal sodat die idioom gewoonlik maklik en probleemloos vertaal kan word. Dit is egter by gevalle waar daar nie 'n verhouding van absolute ekwivalensie en kongruensie bestaan nie, dat vertalers probleme ondervind tydens die vertaling van idiome. In die volgende gedeelte sal gekyk word na die wyse waarop hierdie probleem hanteer kan word deur die bewerking van die vertaalekwivalent te verbeter om vertalers genoegsaam te help om die korrekte vertaalekwivalent vir 'n betrokke idioom binne ' $n$ betrokke konteks te kan opspoor.

\subsection{Divergensie}

Dit gebeur dikwels dat daar vir 'n brontaalidioom meer as een vertaalekwivalent in die doeltaal bestaan, maar dat die onderskeie vertaalekwivalente slegs gedeeltelike sinonieme is of selfs verskillende polisemiese waardes van die brontaalidioom verteenwoordig. By hierdie gevalle is dit veral belangrik dat die leksikograaf die vertaler genoegsaam sal help om te verseker dat die korrekte vertaalekwivalent binne die korrekte konteks gebruik sal word.

In die geval van leksikale divergensie waar daar 'n verhouding van gedeeltelike ekwivalensie tussen die onderskeie vertaalekwivalente bestaan, is dit eerstens belangrik dat daar vir die woordeboekgebruiker aangedui sal word dat die vertaalekwivalente nie absoluut ekwivalent aan mekaar is nie, maar slegs gedeeltelik. Indien die bron- en doeltaalidiome slegs gedeeltelik ekwivalent is as gevolg van byvoorbeeld registerverskille, is dit nodig dat die leksikograaf nie net die verskille aan die gebruiker sal uitwys nie, maar ook die nodige konteks- en/of koteksleiding sal verskaf sodat die gebruiker sal weet watter vertaalekwivalent om binne watter konteks te gebruik. In Artikel 10 kan gesien word hoe 'n gebrek aan konteks- en koteksleiding dit vir die gebruiker baie moeilik maak om te weet watter vertaalekwivalent om binne watter konteks te kies. 
... s.o. is in $~$ for s.t. iem. kom vir iets in aanmerking, iem. het 'n kans op iets ...

Artikel 10: "line" (uit PAEW)

Dit is veral belangrik dat leksikograwe genoegsame leiding aan woordeboekgebruikers sal verskaf in die geval van semantiese divergensie (met ander woorde in gevalle waar die brontaalidioom polisemies is). Soos gesien kan word in Artikel 11, word poliseme in GW en PAEW tans slegs aangedui met behulp van 'n kommapunt. Daar word gevolglik aan die woordeboekgebruiker min of geen addisionele inligting gegee om te help om die korrekte vertaalekwivalent vir die betrokke teks of konteks te kies nie.

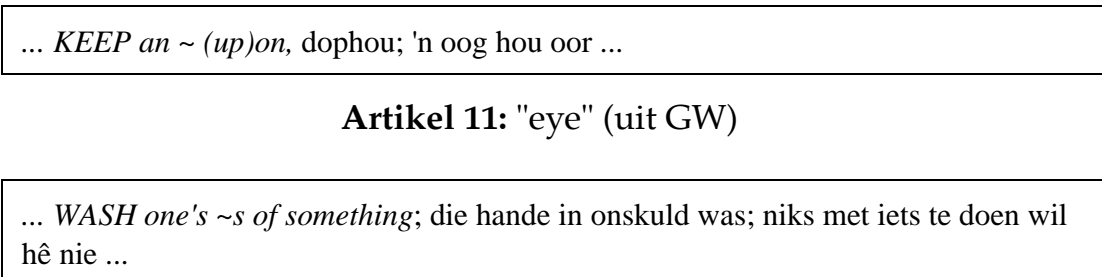

Artikel 12: "hand" (uit GW)

Artikel 11 en Artikel 12 is voorbeelde van artikels waar daar semantiese divergensie voorkom. Nie net word daar nie aan die gebruiker uitgewys wat die betekenisverskille tussen die onderskeie vertaalekwivalente is nie, maar die gebruiker weet boonop ook nie watter vertaalekwivalent om binne watter tipe teks en/of konteks te gebruik nie. Daar word verder nie vir die gebruiker aangedui dat slegs een van die vertaalekwivalente ' $n$ idioom is en die ander net ' $n$ betekenisverklaring nie. Dit is dus belangrik dat die leksikograaf aan die woordeboekgebruiker die nodige konteks- en koteksleiding sal verskaf en die gebruiker op die verskillende betekenisonderskeidinge sal attent maak. Dit kan gedoen word met behulp van glosse of voorbeeldmateriaal. Deur glosse met aanvullende inligting soos in Artikel 13 en Artikel 14 in te voeg, word die bewerking gebruikersvriendeliker gemaak. Die leksikograaf moet egter konsekwent te werk gaan by die invoeging van glosse. Hulle moet nie net lukraak gebruik word nie. Dit is belangrik dat alle vertaalekwivalente waarvan die konteks of betekenis onduidelikheid kan veroorsaak, van glosse voorsien sal word. Slegs in gevalle waar daar geen onduidelikheid bestaan ten opsigte van die konteks of betekenis nie, kan die glosse as konteks- of betekenisleiding weggelaat word (byvoorbeeld by die tweede vertaalekwivalent in Artikel 14). Vanuit die oogpunt van vertalers is die invoeging van hierdie addisionele inligting veral belangrik omdat hulle gewoonlik onder tyddruk werk en dus so vinnig moontlik by die korrekte vertaalekwivalent moet uitkom. Deur die glosse in te voeg word die vertalers se soektog beperk tot net een woordeboek en hoef hulle nie nog ander bronne ook te raadpleeg om vas te stel binne watter teks en konteks die betrokke vertaalekwivalente gebruik moet word nie. 
Aangesien vertalers en ander woordeboekgebruikers gewoonlik heel eerste gaan soek na 'n doeltaalidioom waarmee die brontaalidioom vertaal kan word, is dit dus belangrik dat die onderskeie vertaalekwivalente ook sodanig gelys sal word, met ander woorde deur eers die vertaalekwivalente te gee wat wel idiome is en daarna dié wat slegs enkelwoorde of omskrywings is (sien Artikel 13 en Artikel 14).

... WASH one's s of something; die hande in onskuld was (nie verantwoordelikheid aanvaar nie); niks met iets te doen wil hê nie ...

Artikel 13: "hand" (aangepas uit GW)

... KEEP an (up)on, 'n oog hou oor (sorg vir); dophou (dikwels met 'n onvriendelike bybedoeling) ...

Artikel 14: "eye" (aangepas uit GW)

Ook in gevalle waar daar polidivergensie in die artikel voorkom, is dit belangrik dat daar genoegsame leiding aan die gebruiker verskaf sal word om vinnig en maklik die korrekte vertaalekwivalent te kan identifiseer. In Artikel 15 kan gesien word hoe die bewerking van die idioom "break down" met behulp van konteksleiding verbeter kan word en hoeveel makliker dit is om die korrekte vertaalekwivalent in hierdie aangepaste artikel op te spoor.

... DOWN, inmekaarsak, beswyk (neerval of sterf); in trane uitbars (huil); bly steek (bly staan); teëspoed kry (voertuigprobleme); onklaar raak (breek of gaan staan); ontleed (in dele skei of analiseer) ...

Artikel 15: "break" (aangepas uit GW)

\subsection{Zero-ekwivalensie en surrogaatekwivalensie}

Net soos by sommige enkelwoorde, bestaan daar ook by idiome gevalle van zero-ekwivalensie, met ander woorde waar daar geen vertaalekwivalente in die doeltaal aanwesig is nie. Dit is egter steeds belangrik dat leksikograwe sulke idiome in die woordeboek sal opneem en dan van ' $n$ betekenisomskrywing of 'n surrogaatekwivalent sal voorsien.

Omdat die woordeboekgebruiker uitgaan van die veronderstelling dat indien die brontaalitem ' $\mathrm{n}$ idioom is, die doeltaalitem ook ' $\mathrm{n}$ idioom sal wees, is dit belangrik dat die leksikograaf dit pertinent aan die woordeboekgebruiker sal uitwys wanneer 'n idioom van 'n surrogaatekwivalent voorsien word (met ander woorde wanneer die vertaalekwivalent nie ' $n$ idioom is nie) sodat die gebruiker sal weet dat die betrokke vertaalekwivalent slegs 'n betekenisomskrywing of 'n enkelwoord is wat dieselfde betekenis as die brontaalidioom 
dra. Dit kan gedoen word deur surrogaatekwivalente van 'n eenvoudige struktuurmerker te voorsien soos byvoorbeeld 'n asterisk $\left({ }^{*}\right)$ of iets soortgelyks $(\square, \phi$ of $\bullet)$ soos in Artikel 16 en Artikel 17 getoon.

... GO to great (all) $\sim$ s, *alles in jou vermoë doen ...

Artikel 16: "length" (aangepas uit GW)

$\ldots \sim$ of mind $\neg$ gemoedsrus, $\square$ gerustheid ...

Artikel 17: "peace" (aangepas uit PAEW)

\subsection{Vals vriende (faux amis)}

Nog 'n moontlike probleem waarvan leksikograwe woordeboekgebruikers bewus moet maak, is die voorkoms van vals vriende (ook bekend as "faux amis"). Vals vriende is gevalle waar dit lyk asof daar 'n ekwivalentverhouding tussen twee woorde (of idiome) op grond van sekere ooreenkomste bestaan, terwyl die twee woorde (of idiome) inderwaarheid nie ekwivalent aan mekaar is nie) (sien ook Gouws et al. 2004: 797-806 vir meer inligting oor vals vriende). Hayward en Moulin (1984: 190) beskryf vals vriende soos volg:

Confusion arises because word A (which belongs to the foreign language ...) looks or sounds exactly or nearly like word B, which belongs to the ... mother tongue. The user then establishes an unwarranted interlingual equivalence on the basis of this total or partial similarity.

Een so 'n voorbeeld van vals vriende is die idiome "to pepper someone" en "om iemand te peper". Die betekenis van die Engelse idioom "to pepper someone" is om iemand met vrae te bestook, terwyl die Afrikaanse uitdrukking "om iemand te peper" beteken om iemand te slaan (Prinsloo 2004: 274). Dit is belangrik dat die leksikograaf die gebruiker daarop attent sal maak dat "to pepper someone" nie vertaal kan word met "om iemand te peper" nie (sien Artikel 18). Dit kan byvoorbeeld gedoen word met behulp van 'n glos of addisionele nota na die idioom.

$\ldots \sim$ s.o./s.t. with ... iem./iets met ... bestook (vrae ens.) [nie iemand peper met ... nie] ...

Artikel 18: "pepper" (aangepas uit PAEW)

Dieselfde geld ook vir die idioom "make out with someone" en die uitdrukking "met iemand uitmaak". Terwyl die Engelse idioom beteken om met iemand te vry, beteken die Afrikaanse uitdrukking om 'n verhouding met iemand te beëindig. Alhoewel die twee uitdrukkings dus eenders lyk, is hulle betekenisse 
baie verskillend sodat dit weereens belangrik is dat die leksikograaf die woordeboekgebruikers daarvan bewus sal maak (sien Artikel 19).

... out with s.o., (Am., infml.) 'n vryery met iemand hê [Let wel: Hierdie idioom kan nie vertaal word as met iemand uitmaak nie] ...

Artikel 19: "make" (uit PAEW)

Sodoende kan die leksikograaf die vertaler help om te voorkom dat idiome verkeerd vertaal word as gevolg van vals vriende wat in die doeltaal voorkom.

\subsection{Regstreekse vertalings (leenvertalings)}

Nog iets waarvoor leksikograwe moet sorg by die bewerking van idiome in tweetalige woordeboeke is om woordeboekgebruikers (en vertalers) daarvan bewus te maak dat, alhoewel sommige idiome dikwels in die spreektaal regstreeks vertaal word, die regstreekse vertaling (ook genoem "leenvertaling" of "calque") nie altyd die korrekte een is nie. Voorbeelde van sulke gevalle is die Engelse idiome "born with a silver spoon in one's mouth" en "blood is thicker than water". Hierdie idiome word dikwels direk vertaal as "met die silwer lepel in die mond gebore wees" en "bloed is dikker as water", terwyl hulle korrekte Afrikaanse vertalings is "met 'n goue lepel (in die mond) gebore wees" en "bloed kruip waar dit nie kan loop nie".

Weereens, net soos in die geval van vals vriende, kan leksikograwe glosse of notas gebruik om die woordeboekgebruiker (en veral die vertaler) attent te maak op die feit dat hierdie idiome dikwels verkeerd vertaal word (sien Artikel 20 en Artikel 21).

... born with a SILVER in one's mouth, met 'n goue lepel gebore wees [nie 'n silwer lepel nie]; 'n gelukskind wees ...

Artikel 20: "spoon" (aangepas uit GW)

$\ldots \sim$ is thicker than water bloed kruip waar dit nie kan loop nie [nie bloed is dikker as water nie] ...

Artikel 21: "blood" (aangepas uit PAEW)

\subsection{Register}

Die register van idiome en hulle vertaalekwivalente is ook iets wat leksikograwe duidelik aan woordeboekgebruikers moet uitwys. Dit gebeur dikwels dat die brontaalidioom binne een register val, terwyl die doeltaalidioom se regis- 
ters nie almal dieselfde is as dié van die brontaalidioom nie. In sulke gevalle is dit belangrik dat leksikograwe etikette sal gebruik om die verskillende registers aan te dui, anders kan dit maklik gebeur dat 'n vertaalekwivalent vir 'n idioom gekies word waarvan die register nie ooreenstem met dié van die brontaalidioom nie.

Woordeboekgebruikers gaan gewoonlik van die veronderstelling uit dat indien die register van 'n woord of idioom nie aangedui is nie, die woord of idioom se register neutraal is. Tog is dit nie altyd die geval nie.

In PAEW word die register van die idioom "spill the beans" aangedui by sy bewerking onder die lemma "bean" (Artikel 22), maar daar is geen aanduiding van register by sy bewerking onder "spill" (Artikel 23) nie. Die woordeboekgebruiker word ook nie ingelig wat die register van die vertaalekwivalente is en of hulle register dieselfde as dié van die brontaalidioom is nie.

$$
\text { ... spill the } \sim s \text {, (infml.) die aap uit die mou laat, met die (hele) mandjie patats uitkom ... }
$$

Artikel 22: "bean" (uit PAEW)

$$
\ldots \sim \text { the beans, die aap uit die mou laat ... }
$$

Artikel 23: "spill" (uit PAEW)

Dit is nie net belangrik dat die aanduiding van die register konsekwent sal geskied nie, maar ook dat alle gevalle waar die register van die idiome nie neutraal is nie, aan die woordeboekgebruiker uitgewys sal word met behulp van etikette, glosse of konteks- of koteksleiding.

Dit is meestal net die brontaalitems wat in GW en PAEW gemerk word, terwyl doeltaalitems oor die algemeen ongeëtiketteer gelaat word. In 'n poging om woordeboekgebruikers te help om nie net kommunikatiewe ekwivalensie te bereik nie, maar ook registerekwivalensie, is dit egter belangrik dat ook die register van die doeltaalitems vir die woordeboekgebruiker, veral die vertaler, aangedui sal word. Indien daar van die vertaler verwag word om die doelteks formeler of informeler as die bronteks te skryf, is dit byvoorbeeld nodig om te weet watter idiome binne die betrokke tekste en/of kontekste aanvaarbaar sal wees. Ook in gevalle waar die register van die bronteks juis in die doelteks behoue moet bly, is dit belangrik dat daar vir die vertaler aangedui sal word binne watter register die onderskeie vertaalekwivalente gebruik kan word.

... be at someone's and CALL, tot iem. se diens wees; iem. se Klaas wees (infml.); altyd vir iem. klaar moet staan ...

Artikel 24: "beck" (aangepas uit GW)

In Artikel 24 kan gesien word hoe die invoeging van registeretikette soos "infml." dit vir vertalers en ander woordeboekgebruikers makliker maak om te 
kan onderskei watter doeltaalidiome se register nie ooreenstem met dié van die brontaalidioom nie.

\section{Taalbousels}

Die laaste aspek waaraan leksikograwe by die bewerking van idiome in tweetalige woordeboeke kan aandag gee, is die hantering van die verskillende tipes taalbousels (opsionele bykomstige taalbousels, opsionele bykomstige negatiewe woorde en alternatiewe bykomstige taalbousels). Dit is belangrik dat leksikograwe ' $n$ stelsel sal hê waarvolgens elk van hierdie onderskeie tipes taalbousels bewerk sal word.

In die geval van opsionele bykomstige taalbousels, soos byvoorbeeld "hele" en "both" in Artikel 25 en Artikel 26 hieronder, werk die gebruik van hakies goed. Dit is belangrik dat leksikograwe alle opsionele bykomstige taalbousels pertinent sal merk sodat woordeboekgebruikers dit nie vir wesenlike dele van die idioom sal aansien nie. Deur die opsionele taalbousels tussen hakies te plaas, kan vertalers wat die betrokke idiome moet vertaal, duidelik sien watter dele van die idiome wesenlike dele en watter dele opsionele taalbousels is.

spill the $\sim s, \ldots$ met die (hele) mandjie patats uitkom ...

Artikel 25: "bean" (uit PAEW)

... make (both) s MEET, die tering na die nering sit ...

Artikel 26: "end" (uit GW)

Opsionele bykomstige negatiewe woorde is nog ' $\mathrm{n}$ tipe ekstra waaraan die leksikograaf by die aangawe van idiome in tweetalige woordeboeke spesiale aandag behoort te skenk (Combrink 1989: 59). Volgens Combrink (1989: 60) is die beste leiding wat ' $n$ tweetalige woordeboek aan sy gebruikers in dié verband kan gee, die aanduiding van die basiese idioomvorm en die bykomstige opsionele element(e) as sodanig. Dit is daarom belangrik dat woordeboeke net die idioom in sy negatief sal aangee in gevalle waar die idioom slegs in die negatief gebruik kan word of waar die negatief een of meer vertalings het wat nie uit die positiewe aangawe afgelei kan word nie (Combrink 1989: 60).

... it is no $\sim$ of his/hers dit is nie sy/haar saak nie, dit gaan hom/haar nie aan nie; s.t. is of $\boldsymbol{n o} \sim$ to s.o. iets is vir iemand van geen belang nie; s.t. is of $\sim$ to s.o. iets is vir iemand van belang ...

Artikel 27: "concern" (uit PAEW) 
Die aangawe van die negatiewe vorm in Artikel 27 is dus onnodig en kan weggelaat word aangesien die woordeboekgebruiker maklik genoeg die negatief vanuit die positiewe aangawe kan aflei.

Die laaste groep bousels waaraan leksikograwe spesiale aandag moet skenk, is alternatiewe bykomstige taalbousels. Tans word alternatiewe bykomstige taalbousels wel vir die woordeboekgebruiker aangedui, maar die aanduiding is baie inkonsekwent - in sommige gevalle geskied dit met hakies, in ander gevalle met 'n skuinsstreep en in nog ander gevalle met die woorde "of" of "or". Hierdie verskillende aanbiedings van alternatiewe kan baie verwarrend wees vir gebruikers omdat hulle nie noodwendig sal besef dat dit deurgaans dieselfde tipe bousel is wat bewerk word nie. Dit is daarom belangrik dat die leksikograaf die data op so 'n wyse sal aanbied dat die gebruiker (of vertaler) maklik sal kan aflei wat presies die leksikograaf probeer meedeel en hoe die vertaler die aangebode inligting in die betrokke artikel in sy/haar teks kan of moet gebruik. Dit is dus nodig dat leksikograwe 'n stelsel vir die bewerking van alternatiewe taalbousels sal ontwikkel en dat dit konsekwent dwarsdeur die hele woordeboek toegepas sal word. Aangesien die hakies vir gebruik by opsionele taalbousels aanbeveel is, sou dit wenslik wees indien leksikograwe moontlik hier die skuinsstreep sal gebruik om die verskillende alternatiewe aan te dui (die gebruik van "of" of "or" neem te veel plek op). Die verbeterde bewerkings sal dus soos in Artikel 28 en Artikel 29 daar uitsien.

$$
\begin{aligned}
& \text {... have an } ~ \text { on s.t. 'n ogie/die oog op iets hê ... } \\
& \text { Artikel 28: "eye" (aangepas uit PAEW) } \\
& \text {... GO to great/all } \sim \text { s, alles in jou vermoë doen ... }
\end{aligned}
$$

Artikel 29: "length" (aangepas uit GW)

'n Laaste aspek waaraan leksikograwe by alternatiewe taalbousels aandag moet gee, is die noodsaaklikheid om alternatiewe bousels altyd pertinent aan te dui, anders as by die idioom "to see something in a certain light" in PAEW waar dit so aangegee word dat dit lyk asof die woord "different" 'n wesenlike deel van die idioom is (Artikel 30), terwyl dit eintlik slegs een van verskeie alternatiewe is wat in die idioom gebruik kan word.

... see s.t. in a different $\sim$ iets in 'n ander lig beskou ...

Artikel 30: "light" (uit PAEW)

Die aanbieding van hierdie (sowel as ander soortgelyke) idiome kan dus heelwat verbeter word as daar nie net een van die moontlikhede genoem word nie 
en as die alternatiewe boonop slegs as alternatiewe en nie as wesenlike dele aangedui word nie. Die verbeterde bewerking van hierdie idioom sal dus soos volg lyk:

... see s.t. in a different / bad / good iets in 'n ander / slegte / goeie lig beskou ...

Artikel 31: "light" (aangepas uit PAEW)

Op dié manier word die idioom se alternatiewe taalbousels gelys sodat die bewerking van die idioom wesenlik verbeter word. 'n Vertaler wat met die idioom "to see something in a bad light" gekonfronteer word en dit vervolgens moet vertaal, sal nou maklik kan aflei wat die korrekte vertaalekwivalent vir die idioom is.

\section{Ten slotte}

In die onderstaande artikels kan gesien word hoe die bewerking van idiome verbeter kan word deur van die voorstelle te gebruik wat in hierdie hoofstuk gemaak is. Artikel 32 is die oorspronklike artikel soos dit in GW aangetref word en Artikel 33 is die verbeterde artikel met pyle en annotasies om die verskillende verbeterings uit te wys.

ball $^{2}$, (n) koeël (geweer); bal, bol; kluit; oogappel; muis (van duim); ADDRESS the $\sim$, korrelvat (gholf); of the FOOT, kussinkie (muis) v.d. voet; HAVE the $\sim$ at one's feet, die spel in hande hê; op die punt staan om te slaag; KEEP the $\sim$ rolling, die spel (die saak) aan die gang hou; $N E W \sim$, (cr.), nuwe bal; $N O \sim$, (cr.), foutbal; be ON the $\sim$, wakker, byderhand (gereed) wees; PROVISIONAL , (golf), voorlopige bal; PUT the $\sim$ in the other court, die verantwoordelikheid op jou teenstander skuif; SET (START) the rolling, aan die gang sit, die baan open, die bal aan die rol sit, iets op tou sit, die eerste stoot gee, 'n klip aan die rol sit; and SOCKET, bolskarnier; the $\sim$ is WITH you, dis jou beurt; (v) tot 'n bal vorm; bal.

Artikel 32: "ball2" (uit GW)

Soos gesien kan word, bestaan daar heelwat moontlikhede en maniere waarop die huidige bewerking in tweetalige woordeboeke aangepas kan word om gebruikersvriendeliker te wees en boonop vertalers te help om vinniger en makliker by die korrekte vertaalekwivalent vir ' $n$ betrokke idioom binne ' $n$ spesifieke teks of konteks uit te kom.

Dit is egter belangrik dat leksikograwe ook sal aandag gee aan die voortekste-afdeling van die woordeboek en dat daar aan gebruikers 'n omvattende en bruikbare toeligtingsteks verskaf sal word wat verduidelik presies hoe die lemmas, sublemmas en ook idiome, in die woordeboek bewerk word en waarvoor die onderskeie struktuurmerkers, hakies, skuinsstrepe, e.s.m. staan. So- 
doende kan leksikograwe daarin slaag om vertalers en ander woordeboekgebruikers te help om idiome met groter sukses te vertaal.

\begin{tabular}{|c|c|c|}
\hline $\begin{array}{l}\text { Die kitstoegangstruk- } \\
\text { tuur word verbeter } \\
\text { deur idiome in 'n } \\
\text { aparte teksblok aan te } \\
\text { bied en met ' } n \text { struk- } \\
\text { tuurmerker te merk. }\end{array}$ & $\begin{array}{l}\text { ball }^{2} \text {, (n) koeël (geweer); bal, bol; kluit; oogappel; muis (van } \\
\text { duim); ADDRESS the , korrelvat (gholf); of the FOOT, } \\
\text { kussinkie (muis) v.d. voet; NEW ball,(cr.), nuwe bal; NO ball, }\end{array}$ & \begin{tabular}{|l|} 
Kollokasies en idio- \\
me word van mekaar \\
geskei.
\end{tabular} \\
\hline $\begin{array}{l}\text { In gevalle waar daar } \\
\text { slegs surrogaatekwiva- } \\
\text { lente verskaf is, maar }\end{array}$ & $\begin{array}{l}\text { (cr.), foutbal; PROVISIONAL ball, (golf), voorlopige bc } \\
\text { vand SOCKET, bolskarnier. }\end{array}$ & $\begin{array}{l}\text { tussen letterlike en } \\
\text { nieletterlike idiome } \\
\text { getref. }\end{array}$ \\
\hline $\begin{array}{l}\text { daar tog geskikte DT- } \\
\text { idiome bestaan, is die } \\
\text { idiome ingesluit. DT- } \\
\text { idiome is eerste gelys, } \\
\text { en surrogaatekwivalen- } \\
\text { te daarna. }\end{array}$ & $\begin{array}{l}\text { IDM. HAVE the } \sim \text { at one's feet, die spel in hande hê; op die } \\
\text { punt staan om te slaag*; KEEP the ball rolling, die saak aan } \\
\text { diegang hou, die spel aan die gang hou (lett.); be ON the ball }\end{array}$ & $\begin{array}{l}\text { Opsionele taalbou- } \\
\text { sels is tussen hakies } \\
\text { aangedui. }\end{array}$ \\
\hline & $\rightarrow$ (inf.), op jou kop wees (infml.), (op en) $\leftarrow$ wakker (infml.), & \\
\hline $\begin{array}{l}\text { Registeretikette is in } \\
\text { sowel die BT as die } \\
\text { DT verskaf. }\end{array}$ & $\begin{array}{l}\text { byderhand/geteed wees*; PUT the ball in the other court, die } \\
\text { verantwoordelikheid op jou teenstander skuif; SET / START) }\end{array}$ & $\begin{array}{l}\text { Alternatiewe taalbou- } \\
\text { sels is m.b.v. skuins- } \\
\text { strepe van mekaar } \\
\text { geskei. }\end{array}$ \\
\hline $\begin{array}{l}\text { Idiome is as sublem- } \\
\text { mas bewerk en die } \\
\text { gemeenskaplike ele- } \\
\text { ment volledig uitge- } \\
\text { skryf en nie met ' } n \text { tilde } \\
\text { vervang nie. }\end{array}$ & $\begin{array}{l}\text { the ball rolling, aan die gang sit, die baan open, die bal aan die } \\
\text { rol sit, iets op tou sit, die eerste stoot gee, 'n klip aandie rol sit; } \\
\text { the ball is WITH you, dis jou beurt; (v) tot 'n bal vorm; bal. }\end{array}$ & $\begin{array}{l}\text { Surrogaatekwivalente } \\
\text { is met 'n asterisk } \\
\text { aangedui. }\end{array}$ \\
\hline
\end{tabular}

Artikel 33: "ball2" (Aangepas uit GW)

\section{Nota}

$\dagger \quad$ In hierdie artikel, sowel as in die verdere aangepaste artikels, is slegs dié aspek verander wat in die voorafgaande gedeelte bespreek is. 'n Volledig verbeterde artikel word aan die einde van die artikel verskaf.

\section{Bronnelys}

\section{Woordeboeke}

Du Plessis, M. (Hoofred.). 2005. Pharos 1, Afrikaans-Engels/English-Afrikaans Woordeboek/Dictionary. Kaapstad: Pharos Woordeboeke.

Eksteen, L.C. 199714. Groot Woordeboek Afrikaans-Engels/Engels-Afrikaans / Major Dictionary Afrikaans-English/English-Afrikaans. Kaapstad: Pharos.

Labuschagne, F.J. en L.C. Eksteen. 19938. Verklarende Afrikaanse Woordeboek. Pretoria: J.L van Schaik.

Schoonees, P.C. (Hoofred.). 1961. Woordeboek van die Afrikaanse Taal. Vierde deel H-I. Pretoria: Staatsdrukker.

\section{Ander bronne}

Combrink, J.G.H. 1989. Wesenlike elemente, ekstras en vulsels in die aangawe van idiome in tweetalige woordeboeke. Botha, T.J.R. (Red.). 1989. Leksikografie en leksikologie: 55-77. Menlopark: Serva-Uitgewers. 
Gouws, R.H. en D.J. Prinsloo. 2005. Principles and Practice of South African Lexicography. Stellenbosch: SUN PReSS.

Gouws, R.H., D.J. Prinsloo en G.-M. de Schryver. 2004. Friends will be Friends - True or False. Lexicographic Approaches to the Treatment of False Friends. Williams, G. en S. Vessier (Reds.). 2004. Proceedings of the Eleventh EURALEX International Congress, EURALEX 2004, Lorient, France, July 6-10, 2004: 797-806. Lorient: Université de Bretagne-Sud, Faculté des Lettres et des Sciences Humaines.

Hayward, T. en A. Moulin. 1984. False Friends Invigorated. Hartmann, R.R.K. (Red.). 1984. LEXeter '83 Proceedings. Papers from the International Conference on Lexicography at Exeter, 9-12 September 1983: 190-198. Tübingen: Max Niemeyer.

Prinsloo, A.F. 2004. Spreekwoorde en waar hulle vandaan kom. Kaapstad: Pharos.

Weiss, J. 2004. Translation Hints. http://www.lyx.org/TranslationHints [24 Februarie 2005]. 